\title{
Analysis of Settlement of the Road with Full Scale Geotextile Reinforcement on the Very Soft Soil (Case Study in Tapin Regency, South Kalimantan)
}

\author{
Muhammad Arsyad ${ }^{1, *}$, Indrasurya B. Mochtar ${ }^{2}$, and Noor Endah Mochtar ${ }^{2}$ \\ ${ }^{1}$ Lambung Mangkurat University, Indonesia \\ ${ }^{2}$ Sepuluh November Institute of Technology, Indonesia
}

\begin{abstract}
, in case of the construction of road in soft soil, it is necessary to consider the use of materials around the road construction site, and not to use selected material which is imported from outside the road construction site. Thus, aim to overcome the difficulties of using selected materials, namely the difficulty to obtain the materials, the price of expensive materials, the freight of material that could takes a long time period, high cost, and the use of materials that tend to be environmentally unfriendly. It is very necessary to learn about the use of nonstandard additive materials, taken to the road construction site, but with the use of geotextile reinforcement. The research method used is a full scale method in the form of trial embankment, so that the performance of the road can be observed for a long period of time due to the traffic and soil settlement. The results obtained is settlement that occur on the road from the combination of ordinary embankment material and local material, most frequently occured in a larger percentage of ordinary embankment than the local material. While the visual value is relevant to the settlement in which a larger percentage of ordinary embankment results in a better visual value, due to the quality of the ordinary embankment material is better than the local material.
\end{abstract}

Keywords: settlement, geotextile reinforcement, substandard material, very soft soil

\section{Introduction}

Considering that soft soil is a badly characterized land as a road embankment foundation, the construction of roads above soft soil such as swamp land in Indonesia is required to use selected material as landfill material. Likewise for the construction of major highways with crowded traffic is better to use the selected material. Such material is soil that meet the requirements of Plastic Index (IP) $<6$ and CBR price $>10$ (Hendarsin, 2000). In some western areas of South Kalimantan, it is rather difficult to obtain, because it can only be

* Corresponding author: emarsyad@gmail.com 
obtained from places a bit far away and expensive, of course. So we need a "breakthrough technology" to find a way out for this case.

For embankments that do not require high strength, ordinary material can be used as embankment material. Hendarsin (2000) conclude that an ordinary material is an embankment material which has the following characteristics:

1. Has a minimum soaked CBR value of $6 \%$.

2. Soils that do not belong to the $\mathrm{CH}$ group in the USCS classification or soil belonging to the A-7-6 subgroup in the AASHTO classification.

3. Excluded/classified as land that has a high expansive potential with LL $>60$ and $\mathrm{IP}>35$, also excluding land that has an activity value of $\mathrm{A}>1.25$; where is the value A according to AASHTO T 258-81.

In addition to the selected material and ordinary material which are used as the landfill, in this research the materials used are not from those two materials, bu usingt the nonstandard material (substandard) which the capacity and the characteristics is lower than such materials. The nonstandard material is taken from the material around the location of the road, which is soft soil.

To deal with the problems with the soft soil, before doing the construction work, firstly it is necessary to have some improvements to this kind of soil, such as using geosynthetic as the reinforcement of the landfill (Hardiyatmo, 2009). The most commonly used geosynthetic material is geotextile material which will function as follows:

1. Geotextile material can be used as a retaining force in the soil so that the capacity of the soil increases.

2. The existence of this geotextile material can also prevent a differential settlement that is too large on the surface of the road.

Geotextile material at the bottom of the embankment also functions as a barrier between the embankment material and the original soil, so that the loss of embankment material entering the subgrade can be reduced (Yelvi, 2008).

Although the use of geotextile is highly recommended for the construction of road over soft soil, there are still some difficulties, namely the necessity of using landfill from ordinary container or selected material for body embankments. This landfill material is often difficult to obtain and expensive because it must be from another place (location) which is far from the construction site, for example from outside the island or outside the area. So the longer the material choice needed in the construction of a road in South Kalimantan will be increasingly expensive. In fact, the use of ordinary embankment and selected material as embankment material is something that must be meet with the standard for road works by Bina Marga (1987) and AASHTO (American Association of State Highway and Transportation Officials).

It is necessary to consider that as much as possible to use the material around the construction site, and not using selected material that is brought in from outside the road construction site. Further, such efforts need to do to overcome the difficulties of using selected materials, namely materials that difficult to obtain, the price of expensive selected materials, freight of selected materials that require a long time, high costs, and the use of selected materials that tend to be environmentally friendly.

It is very necessary to learn about the use of nonselected material embankment (nonstandard), which is taken at the location of the road, but with the use of geotextile reinforcement. Geotextile reinforcement is made in layers according to need. The use of nonselected material with geotextile reinforcement has been carried out in the construction of roads in Irian Jaya, soil improvement is carried out using road fillings from around the existing road and wrapped in geotextile, it can function properly (Mochtar, 2013).

So far, studies related to the use of geotextile in road construction on the soft soil have 
been carried out. However, there is no currently research carried out on road construction on soft soil with geotextile that uses filling material from materials that already available at the nonselected material construction site on a field scale.

The purpose of this research is to analyze the performance (settlement) of the road embankment on soft soil reinforced with material geotextile, if embankment material and nonstandard local material (substandard material) used as filling materials.

\section{Research Methods}

The research method that will be implemented is the full scale method (field scale) in the form of trial embankment, so that the performance of the road can be observed for a considerable period of time due to the presence of traffic and settlement. The data to be taken in the field includes data on soil characteristics to be studied, vertical movements, horizontal movements and embankment surface conditions.

This research activity will be carried out at full scale in the field. The activities are carried out through several stages of activities, such as 1) preparation to make trial embankment, 2) the physical implementation phase of trial embankment, 3) installation / installation of measuring instruments (monitoring), 4) trial embankment performance monitoring phase and 5) results analysis phase.

The phase of preparation to make trial embankment, including the selection of locations that will be used as research sites, then checking the characteristics of subgrade at that location, namely in the form of soil with very soft subgrade conditions. At this phase, it is very important for the next step, before the trial embankment is made. After everything has been prepared, then the next phase is the trial embankment with various conditions as the researcher wanted to do, like trial embankment without reinforcement, only subgrade which has the burden of embankment on its top, also trial embankment with geotextile reinforcement with selected material filling material and trial embankment by geotextile reinforcement with nonselected filling material.

The next step is testing the trial embankment with various conditions to observe settlement, horizontal displacement with some settlement plate equipment, inclinometer and other equipment as needed in the field.

The next step is the analysis of the results of the tests that have been carried out. In this analysis, the analysis should be carried out along with the data obtained so that it can be known whether the tests carried out are in accordance with the plans that have been designed, do not wait until the testing is done. 


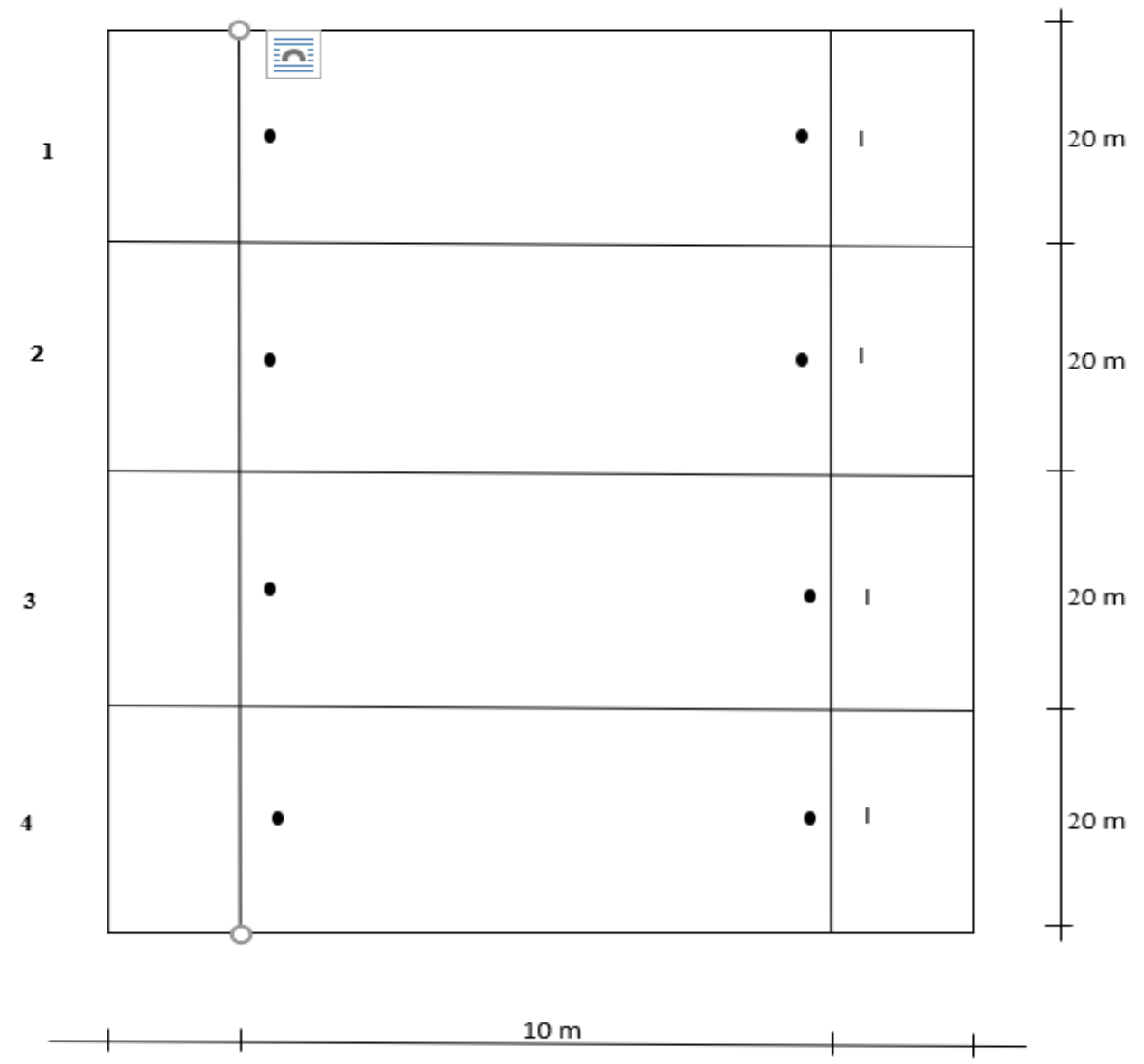

Information:

- Settlement Plate

I Inclinometer

Fig. 1. Appearance of Trial Embankment

Cross section of trial embankment as follows :

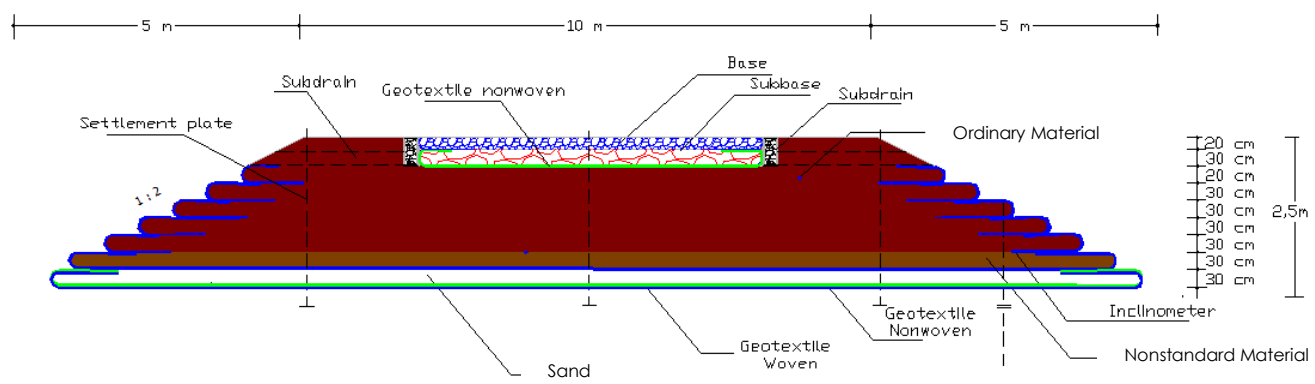

Fig. 2. Cross Section of Trial Embankment 1 


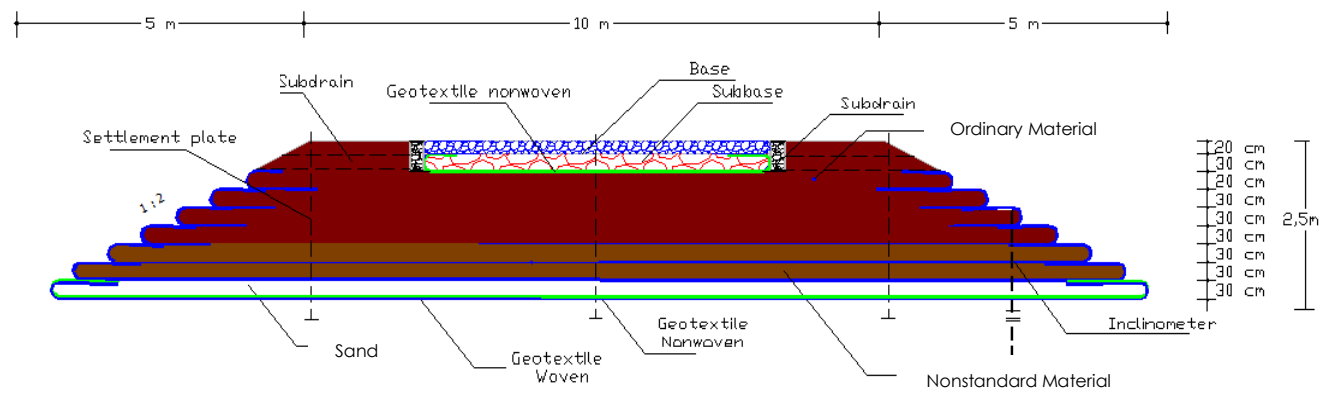

Fig. 3. Cross Section of Trial Embankment 2

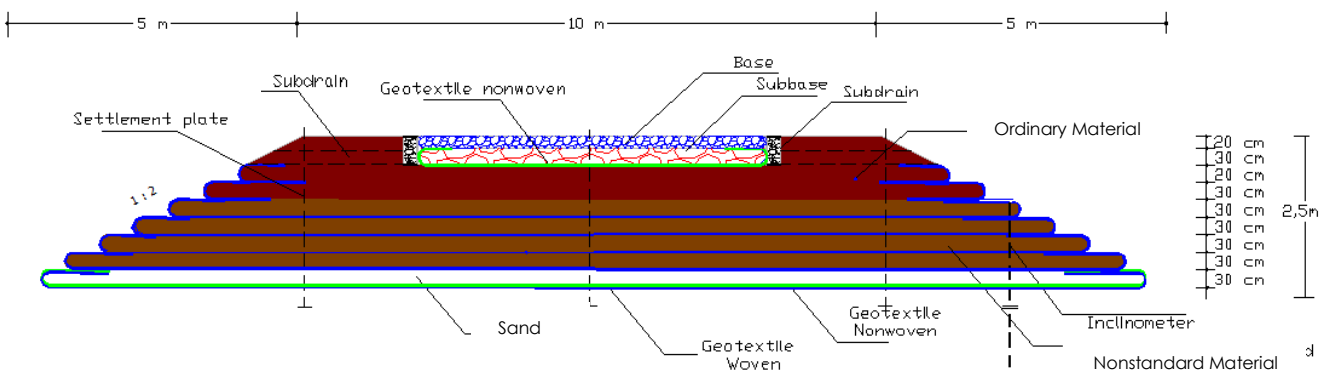

Fig. 4. Cross Section of Trial Embankment 3

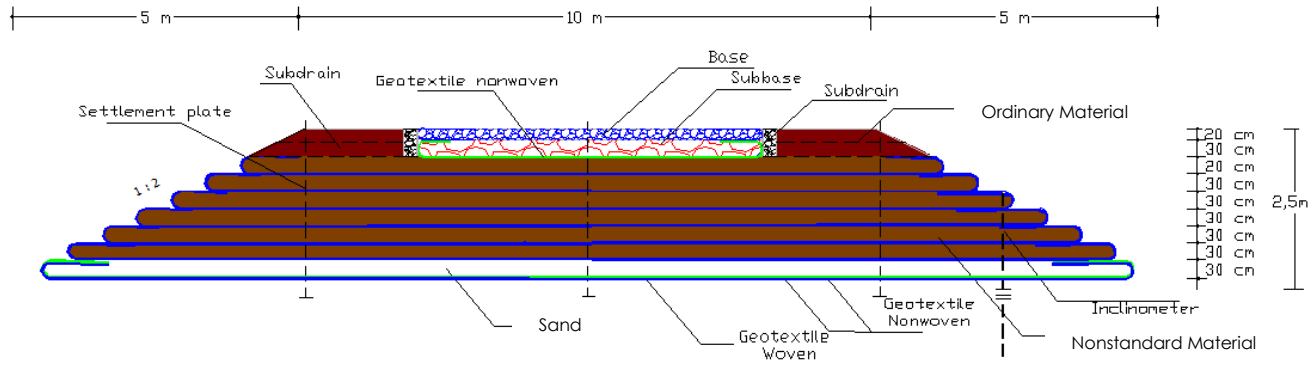

Fig. 5. Cross Setion of Trial Embankment 4

The soil condition around the location is in the form of clay with a volume weight $(\gamma)$ between 1.41-1.58 $\left(\mathrm{gr} / \mathrm{cm}^{3}\right)$ and vane shear test $(\mathrm{Su})$ value $8-27(\mathrm{kPa})$. While the conus (qc) resistance value is very low, namely from a depth of 0 to $8 \mathrm{~m}$ by $1 \mathrm{~kg} / \mathrm{cm}^{2}$, only at a depth of above $8 \mathrm{~m}$ increases to $3 \mathrm{~kg} / \mathrm{cm}^{2}$, a depth of $11 \mathrm{~m}$ to $120 \mathrm{~kg} / \mathrm{cm}^{2}$, and at depth of 12,5 reaches a value of $150 \mathrm{~kg} / \mathrm{cm}^{2}$.

The road of the material used in the form of local soil (soil around the research location), ordinary embankment, sand, split and sand stone, depends on the planned simulation of the trial embankment plan, as shown in Figure 2 to Figure 4. 


\section{Analysis and Discussion}

The settlement occurred at the 6 observation segments as follows:

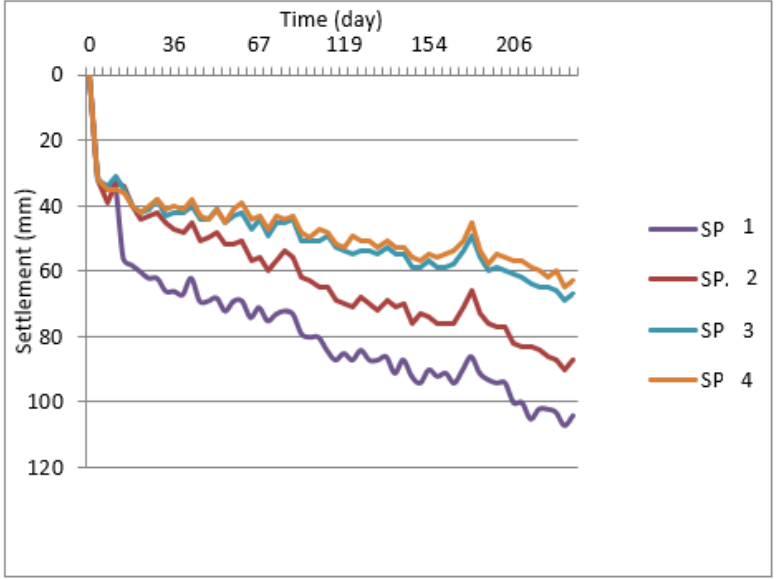

Fig. 6. The Correlation between Settlement due to Time

From the results of the data above, it can be seen that the settlement occurred at, SP3 and SP4, where tends to be a similar downward trend. While the settlement that occurred at SP1 and SP2, until the 15th day the settlement occurred was relatively the same, but after that, there was a difference in the settlement in the following days, where the settlement at SP1 is greater than the settlement at SP2 and others.

Such difference is related to variations in the use of local materials as a substitute for ordinary embankment. For segments 1 , the use of local materials is less than in segment 2 , 3 and 4, so that the results of settlement observations of SP1 are greater than SP2, SP3 and SP4.

A visual observation of trial embankment using values from the type of damage to the road like bumpy road, collapsed roads, puddle on the surface and comfort passed.

The result of the visual observation as follows:

Tabel 1. Visual Observation of Trial Embankment

\begin{tabular}{|c|c|c|c|c|}
\hline \multirow{2}{*}{$\begin{array}{c}\text { Time } \\
\text { (Day) }\end{array}$} & \multicolumn{5}{|c|}{ Segment } \\
\cline { 2 - 5 } & 3 & 4 & 5 & 6 \\
\hline 197 & 0 & 0 & 0 & 31 \\
\hline 206 & 0 & 0 & 6 & 31 \\
\hline 214 & 0 & 0 & 16 & 31 \\
\hline 219 & 0 & 0 & 21 & 40 \\
\hline 234 & 0 & 16 & 31 & 40 \\
\hline 239 & 0 & 16 & 31 & 40 \\
\hline 242 & 6 & 16 & 31 & 40 \\
\hline 246 & 6 & 21 & 31 & 45 \\
\hline 248 & 6 & 21 & 36 & 45 \\
\hline
\end{tabular}




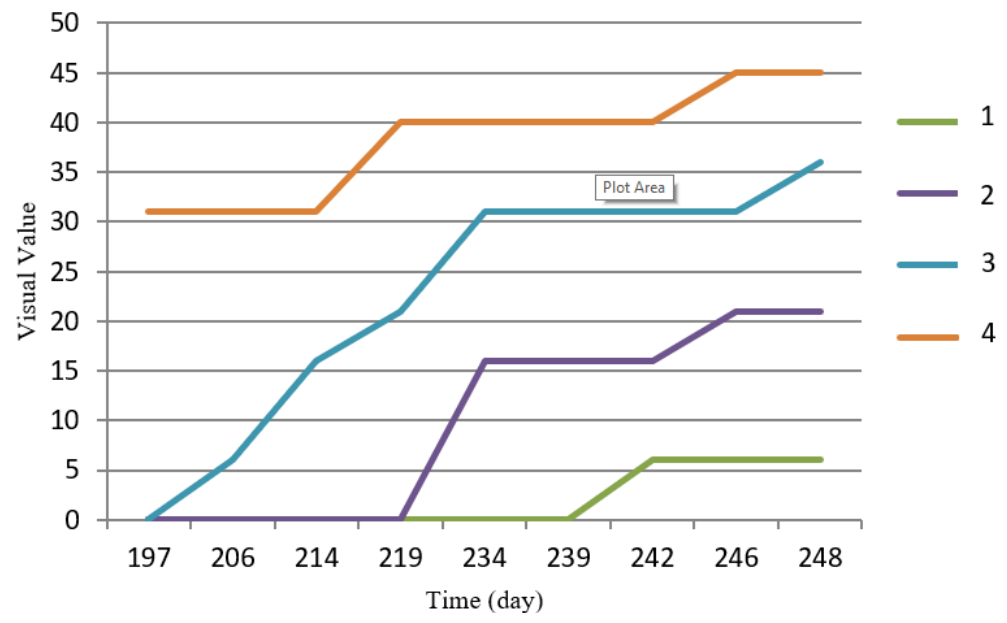

Fig. 7. Correlation of Visual Valuedue to Time

A visual observation of the embankment trial using values of the type of road damage in the form of waves, collapsing and sinking in the jellies; conditions of standing water on the surface and comfort passed. Small visual values indicate that the level of surface damage is still good, while a large visual value illustrates that the level of surface damage is not good. On the figure above, from the results of visual observations it can be seen that the level of road damage at segment 4 simulation is quite bad, where the road is a combination of all using local materials with geotextile reinforcement. Whereas in the conditions at segment 1 uses a combination of materials between ordinary embankment and local material, so that it has better visual value compared to the other segments.

The visual value results are relevant to the settlement plate (SP) reading, for example at segment 1 where the percentage of ordinary embankment used is greater than the other segments, so the weight of the embankment itself is greater and the settlement is greater. Percentage of the greater of ordinary embankment also results in better visual value, due to the better quality of ordinary embankment filling material than local materials.

\section{Conclusion}

From the results of temporary observations and analyzes it can be concluded that:

1. Settlement that occurred at SP3 and SP 4, where tends to be a similar settlement trend. While the settlement that occurred at SP1 and SP2, until the 15th day the settlement occurred was relatively the same, but after that, there was a difference in the settlement in the following days, where the settlement at SP1 was greater than the settlement at SP2 and others.

2. Visual values are relevant to the results of settlement plate (SP) readings. Bigger percentage of ordinary embankment materials results in a better visual value, due to the quality of ordinary embankment materials that are better than local materials. 


\section{References}

1. Das, Braja M., Principles of Geotechnical Engineering, Sixth Edition, California, Chris Carson (2006)

2. Hardiyatmo, H.C., Geosynthetics for Highway Engineering (Geosintetik untuk Rekayasa Jalan Raya), Yogyakarta, Gadjah Mada University Press (2009)

3. Hardiyatmo, H.C., Geosynthetics for Highway Engineering, Design and Application (Geosintetik untuk Rekayasa Jalan Raya, Perancangan dan Aplikasi), Yogyakarta : Gadjah Mada University Press (2013)

4. Hendarsin, Shirley L, Highway Engineering Planning (Perencanaan Teknik Jalan Raya), Bandung, Politeknik Negeri Bandung (2000)

5. Mochtar, Indrasurya B., Road Construction for Oil Drilling Locations PT. Pertamina in Salawati Island, West Papua (Research Report) (2013)

6. Mochtar, Indrasurya B., Lecture Materials on Soil and Foundation Mechanics, ITS, Civil Engineering Department, Surabaya (2015)

7. Yelvi, Bamboo Woven Design That Is Modified As A Substitute For Geotextile To Separate Between The Bottom Base Of The Road And Soft Soil Base (Disain Anyaman Bambu Yang Dimodifikasi Sebagai Bahan Pengganti Geotextile Untuk Pemisah Antara Lapis Pondasi Bawah Jalan Dengan Tanah Dasar Lunak), Rekayasa Sipil, Volume IV, Nomor 1 (2008) 